\title{
11. GEOMORPHOLOGY OF THE PACIFIC CONTINENTAL MARGIN OF THE ANTARCTIC PENINSULA
}

\author{
J.R. Vanney, Universite de Paris-Sorbonne, Institut de Geographie, 191 rue Saint-Jacques (F) 75005 Paris \\ and \\ G.L. Johnson, Office of Naval Research, Code 461, Arlington, Virginia
}

\section{INTRODUCTION}

The marine geomorphology of high latitude regions is especially complex in contrast to temperate regions, because of the presence of glacial activity. A particularly well explored region of Antarctica is along the western border of the Antarctic Peninsula. Because there is an adequate data base for the area, the present study was initiated to investigate the marine geomorphology of the sea bed in this dynamic region.

The region, shown in Figure 1, stimulated exploration due to its proximity to logistic bases (ports) in South America, "relatively" mild climate (Rouch, 1957), accessibility due to lack of ice barriers, and the high marine biologic productivity with resultant marine mammals. British and American whalers and sealers (Palmer, Biscoe, Bransfield), and Th. von Bellingshausen, the Russian explorer, early sailed these waters. The first accurate maps were constructed by the whaler Dallman in the vicinity of Palmer Island (Gourdon, 1914). Later notable scientific expeditions in the vicinity included A. de Gerlache aboard La Belgica in 1898-1899 (Gerlache, 1902), and J. Charcot in 1904-1905 aboard Le Français (Charcot, 1906; Gourdon, 1908). Charcot, onboard Le Pourquot-Pas? (Charcot, 1910; Institut de France, 1910), conducted coastal mapping surveys to latitude $70^{\circ} \mathrm{S}$ (Alexander and Charcot islands), at which point the survey was stopped by the impenetrable ice pack. In the 1930's, Great Britain commenced Antarctic oceanography with the HMS Discovery of the British Graham Land Expedition (1934-1937). Following World War II, interest in the region revived. The U.S. Navy High Jump Operation in 1947, followed by the International Geophysical Year, stimulated research vessels and icebreakers of Argentina, Chile, and Great Britain to explore the region. Additional data were collected by the R/S $O b$ in 1959-1960 and U.S. icebreakers Burton Island, Eastwind, Edisto, Glacier, Northwind, Southwind, Staten Island, and Westwind. Of special value to our studies have been the data collected by the R/V Vema (17-18th Cruises, 1960-1961) and the National Science Foundation sponsored cruises of the Hero and USNS Eltanin (Cruises 5, 6, 10, 11, 21, 23, 42, and 43 ) during which a complete suite of geophysical data were obtained. Tracks covered are noted in fig. 3 of Tucholke and Houtz (this volume).

With relatively dense cover of sounding data in the area and because no further bathymetric work is scheduled for the immediate future, it seems to be an appropriate time to (1) construct a new bathymetric chart, (2) investigate the main geomorphic provinces, and (3) discuss the possible evolution of the continental margin in relation to the recent discoveries and interpretations of the southeastern Pacific. Delineation of physio- graphic provinces is also discussed in this volume by Tucholke and Houtz. The region covers $1.5 \times 10^{6} \mathrm{~km}^{2}$, an area comparable to the Atlantic continental shelf of the United States or the northwestern Europe epicontinental seas as a whole.

\section{MORPHOLOGY}

\section{Antarctic Peninsula}

As is evident in Figures 1 and 2, the Antarctic "Panhandle" is a peninsular arc bordered by numerous archipelagoes which extend as lineaments southward from the main islands of South Shetland, Palmer, Biscoe, Adelaide, Alexander, and Charcot. The coastal lands are elevated generally more than 2000 meters with a maximum of 2820 meters on Anvers Island (Figure 3). The northwestern archipelagoes and capes are ice free, sculpted in rugged cliffs and deep fjords which were mistaken by early explorers as straits connecting the Bellingshausen and Weddell seas. The number of glaciers debouching into the fjords increases southward where the Antarctic climate becomes dominant. The ice, covering the inland plateaus with a surprisingly even surface, flows down to the sea forming ice cliffs (60-80 $\mathrm{m})$ which are the most common form of coastal relief. Rock outcrops on the inland plateaus are limited to nunataks. The ice cuts either into the rocky substratum or incises the pebble beaches (Flores Silva, 1952). It is only south of latitude $69^{\circ} \mathrm{S}$ that the ice extends seaward as floating ice shelves such as the Wordie, Wilkins, and Bach ice shelves (the latter two are south of the limits of Figure 1). The glaciated rocky coastlines of the mainland and adjacent islands are adjoined by numerous bevelled rocks and reefs at water level, producing a coastal landscape similar to the "strandflat" of Scandinavia (Holtedahl, 1929).

The outline of the coast and its intricate contours are controlled by geologic structures such as (1) scarps which are well developed because of the intercalation of sills and volcanic agglomerates in the Meso-Cenozoic marine layers of the Andean Series, (2) outcrops of the resistant metamorphic and volcanic rocks, (3) fault controlled headlands and fjords, and (4) the submerged caldera of Deception Island. This structural influence has been analyzed in recent works reviewed by Adie $(1964,1972)$. Stepped marine terraces and elevated beaches (Figure 3) are described on Livingstone Island (South Shetlands) and Marguerite Bay (Adie, 1964; Nichols, 1960, 1964; Calkin and Nichols, 1972) to be between 3 and 275 meters high; this elevation is partly due to the glacio-isostatic rebound.

Glacial erosion, of which the fjords are the most obvious traces, emphasizes the geologic structure. It is difficult to determine the role played by ice in the shaping 


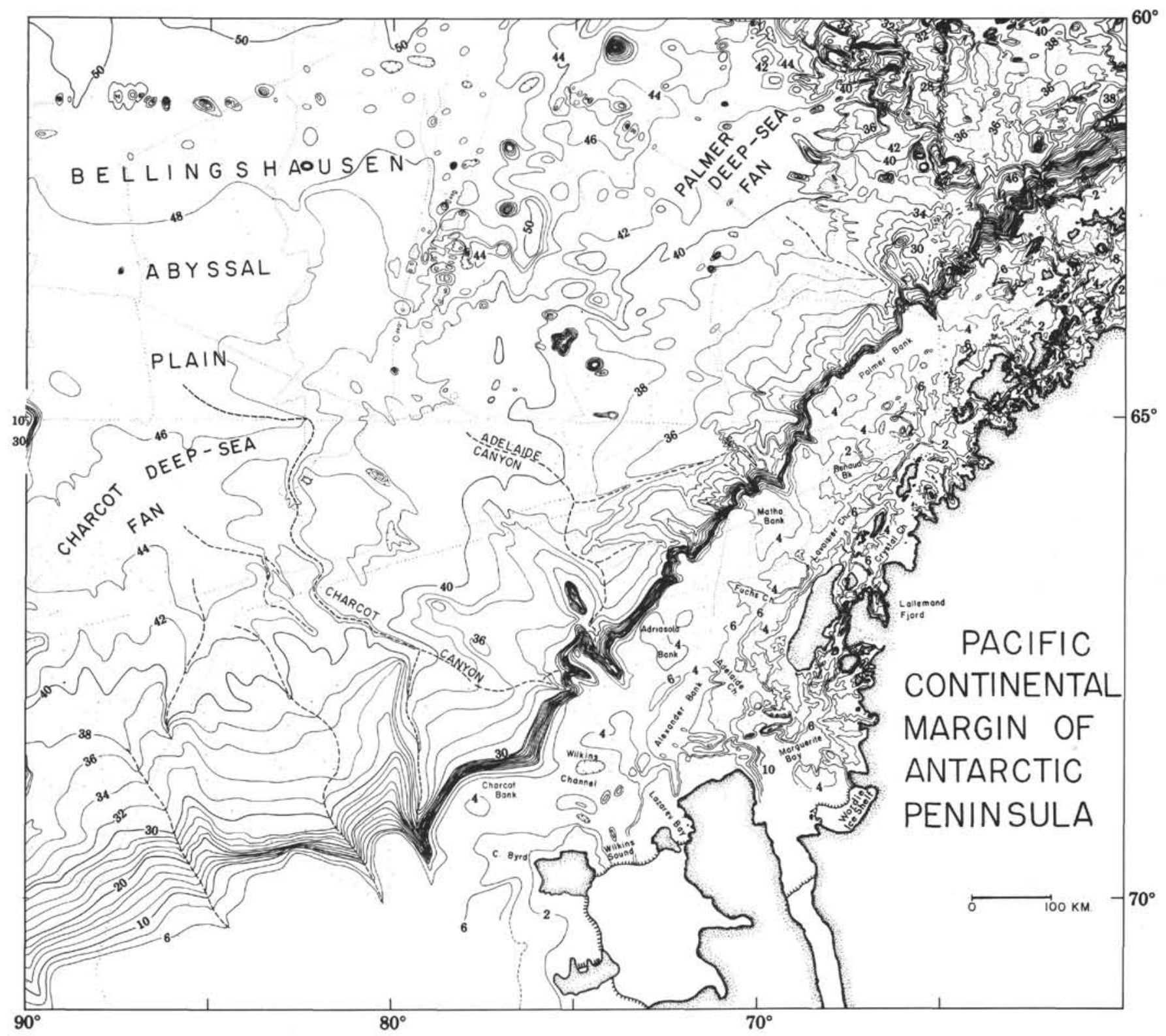

Figure 1. Bathymetric map of the Pacific continental margin of Antarctic Peninsula (Mercator projection). Contours in corrected meters. Contour interval: 200 meters. The numerous sounding in the coastal areas are not shown.

of stepped landscapes such as those of Livingstone Island, which apparently are not strandflats but, rather, marine eroded surfaces. The northern shores of the islands generally lack beaches, presumably being protected by extensive sea ice which permitted limited wave erosion (Fuenzalida, 1964). More prominent are the signatures of periglacial and "glacial" (drift ice) processes such as gravel beaches with a gelifraction and solifluction mantle, patterned grounds, glacial marine ablation and deposition (Gourdon, 1908; Joyce, 1950; Warnke and Richter, 1970; Flores Silva, 1972; Araya and Herve, 1972).

\section{Continental Shelf}

The width of the continental shelf increases from north to south. West of the South Shetland Islands, in the north, the shelf is less than $200 \mathrm{~km}$ wide, whereas to the west of Charcot Island it largely exceeds $300 \mathrm{~km}$ (Figures 2 and 4).

\section{The Inner Shelf}

At the periphery of the peninsula and major islands and offshore strandflat zone, there extends a narrow belt characterized by a rough and jagged topography. Seismic profiles are not available for the area, but the craggy form of the sea bed indicates the presence of a rocky substratum. This probably represents an eroded portion of the Antarctic mountains which underwent, during the Pleistocene, the alternate action of gelifraction and active erosion by the glaciers. Narrow depressions separated by steep rocky ridges parallel to 


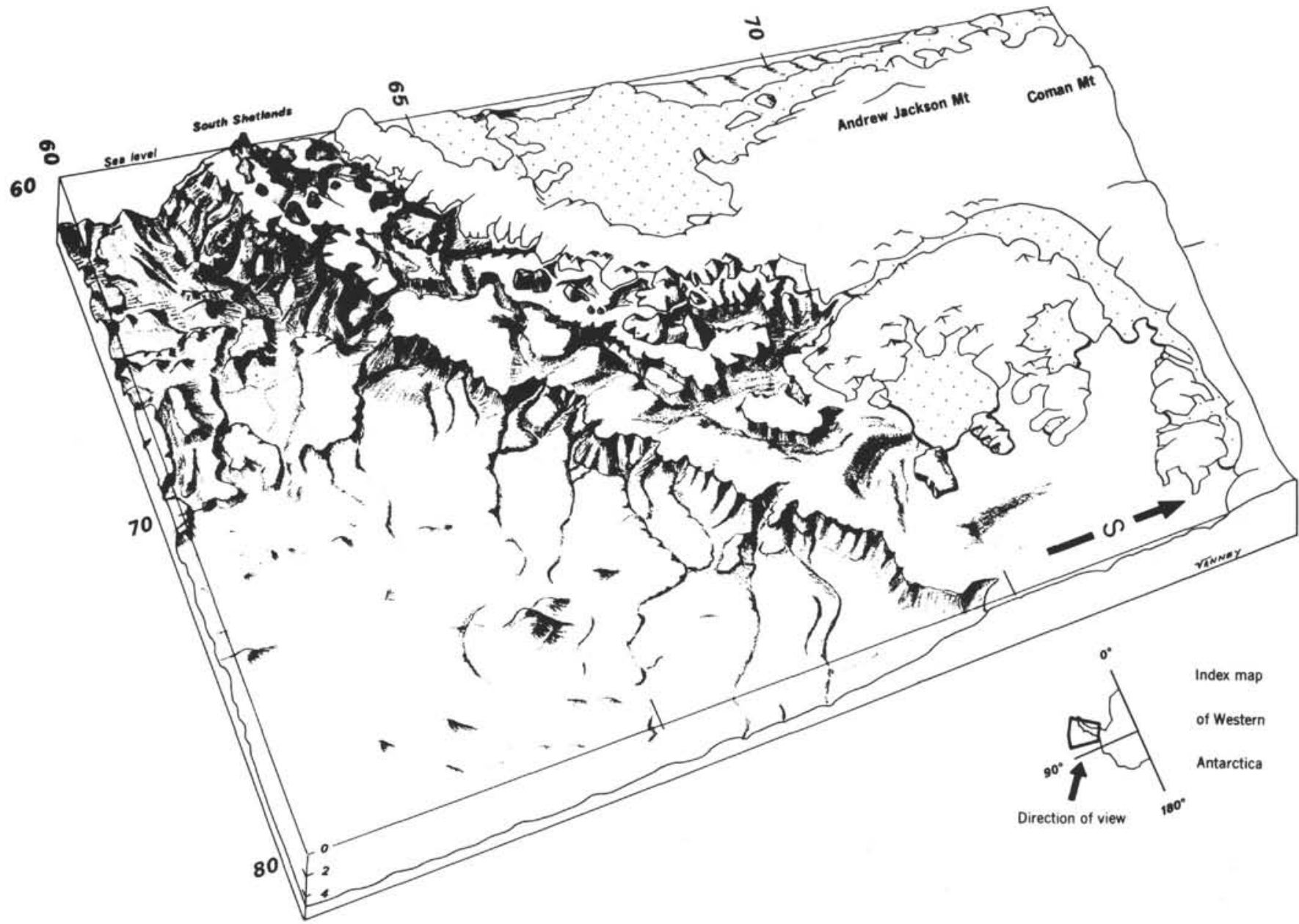

Figure 2. Block diagram of the Antarctic Peninsula and its continental margin.

the coastline are in alignment with the principal directions of the folding and faulting.

\section{The Outer Shelf}

The edge of the platform is $400-500$ meters deep and, in some places, more than 600 meters deep (Zhivago and Evteev, 1970) (Figure 4). Additional bathymetric profiles of the shelf edge and upper slope are presented in Figure 5 of Tucholke and Houtz (this volume). The depth at the edge decreases northward to the extreme north of the peninsula where it usually lies between 200 and 300 meters. In this outer zone are found undulating plains with banks ("border banks" in the Soviet literature). They are, from north to south: Palmer, Renaud, Brategg, Matha, Adriasola, Alexander, Wilkins, and Charcot banks (Figure 3). This singular morphology is due most likely to widespread accumulative processes: (1) basal and terminal moraine deposits by inland ice and ice shelves (Carey and Ahmad, 1961) developed during the maximum phases of glaciation; (2) outwash material deposited during the interglacial periods; and (3) presently, glacial marine deposits added by icebergs and floes drifting from the south (Rouch, 1928).

The presence of reworked glacial debris on the distal part of the shelf was revealed by inspection of Eltanin photographs. A photograph of the Eltanin's 5th cruise, Station 21 at $65^{\circ} 57^{\prime} \mathrm{S}, 70^{\circ} 15^{\prime} \mathrm{W}(375 \mathrm{~m})$ shows multiple sizes of subrounded, blocky boulders mixed with an apparently compact mud (Dangeard and Vanney, in press; Dangeard et al., in preparation). The terraine shows a morphological and sedimentological similarity to the Scotian platform (King, 1969, 1970; McLean and King, 1971), and the East Greenland shelf as described by Sommerhoff (1973). Unfortunately the navigational accuracy of the sounding lines is inadequate to determine the exact location of individual morainic ridges. Farther to the west Zhivago and Evteev (1970) observed an apparent ancient shoreline submerged at approximately 300 meters.

\section{Shelf Channels}

The continental shelf is deeply dissected by a pattern of troughs or channels oriented either parallel or perpendicular to the shore of the peninsula (Figure 3). Between the islands, and particularly between the inner and outer zones, long "marginal" channels (according to the terminology of $\mathrm{O}$. and $\mathrm{H}$. Holtedahl) form deep passages, parallel to shore, almost continuously from the South Shetlands to the offshore area of Anvers Island (Bransfield Strait). Both are more than 1200 meters deep. Figure 3 shows this trough topography (in 
J. R. VANNEY, G. L. JOHNSON

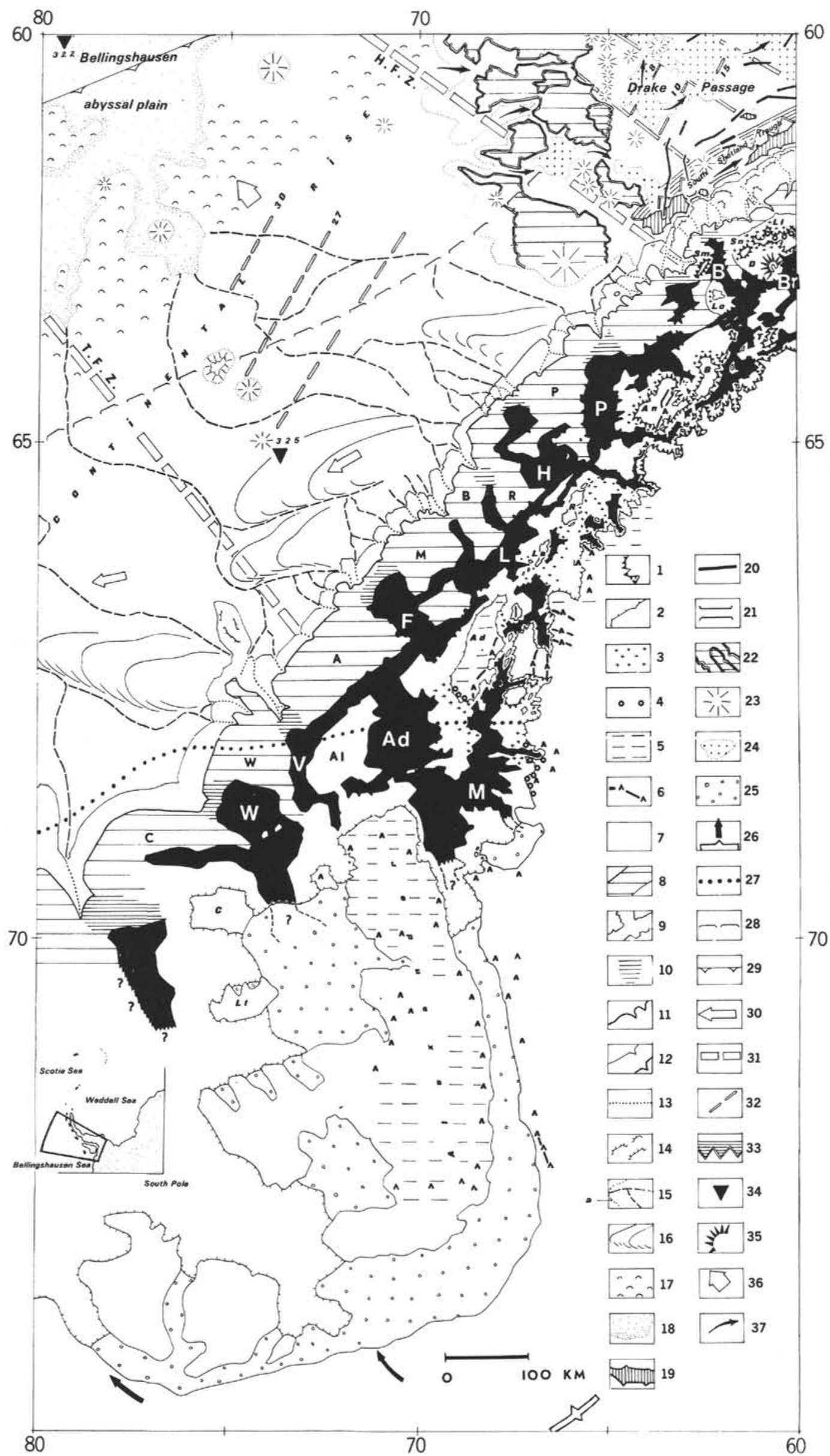


Figure 3. Geomorphic sketch; 1. Rocky cliff and fjord; 2. Ice cliff; 3. Strandflat; 4. Elevated beaches; 5. Fault block coastal mountain; 6. Nunatak and rocky crest line; 7. (white) Inner shelf; 8. Outer shelf; 9. Shelf channels; 10. Counterslope of the transverse channel; 11. Edge of the shelf; 12. Continental slope with steep and graded profile; 13. Axis of canyon; 14. Steps of the continental slope; 15. Deep-sea channel (a: limit of the continental rise); 16. Abyssal drift on the continental shelf; 17. Hummocky belt; 18. Abyssal plain; 19. South Shetland Trough; 20. Ridge of the Drake Passage; 21 . Abyssal gap; 22. Plateau and scarp; 23. Seamount; 24. Isolated depositional basin; 25. Ice shelf; 26. Divide and path of the glaciers; 27 . Extreme limit of permanent pack ice; 28. Ibidem of the seasonal pack ice; 29. Antarctic convergence and approximate limit of the extension of icebergs; 30. Direction of the westward geostrophic contour current; 31. Fracture zone; 32. Magnetic anomaly (age in m.y.); 33. Zone of subduction; 34. Drilling site (JOIDES); 35. Active volcano; 36 . Direction of sediment flow to the "Bellingshausen sediment body" (Ewing et al., 1966); 37. Probable eastward extension of the "Bellingshausen sediment body." Abbreviations-Islands: Ad: Adelaide; An: Anvers; B: Brabant; C: Charcot; D: Deception; La: Lavoisier; Li: Livingstone; Lo: Low; Lt: Latady; R: Renaud; Sm: Smith; Sn: Snow; T: Trinity. Banks: A: Adriasola; Al: Alexander; B: Brategg; C: Charcot; M: Matha; P: Palmer; R: Renaud; W: Wilkins. Channels (in black): Ad: Adelaide; B: Boyd; Br: Bransfield; F: Fuchs; H: Hugo; L: Lavoisier; P: Palmer; M: Marguerite; V: Vostok; W: Wilkins. Fracture Zones: H.F.Z., Hero Fracture Zone; T.F.Z., Tula Fracture Zone.
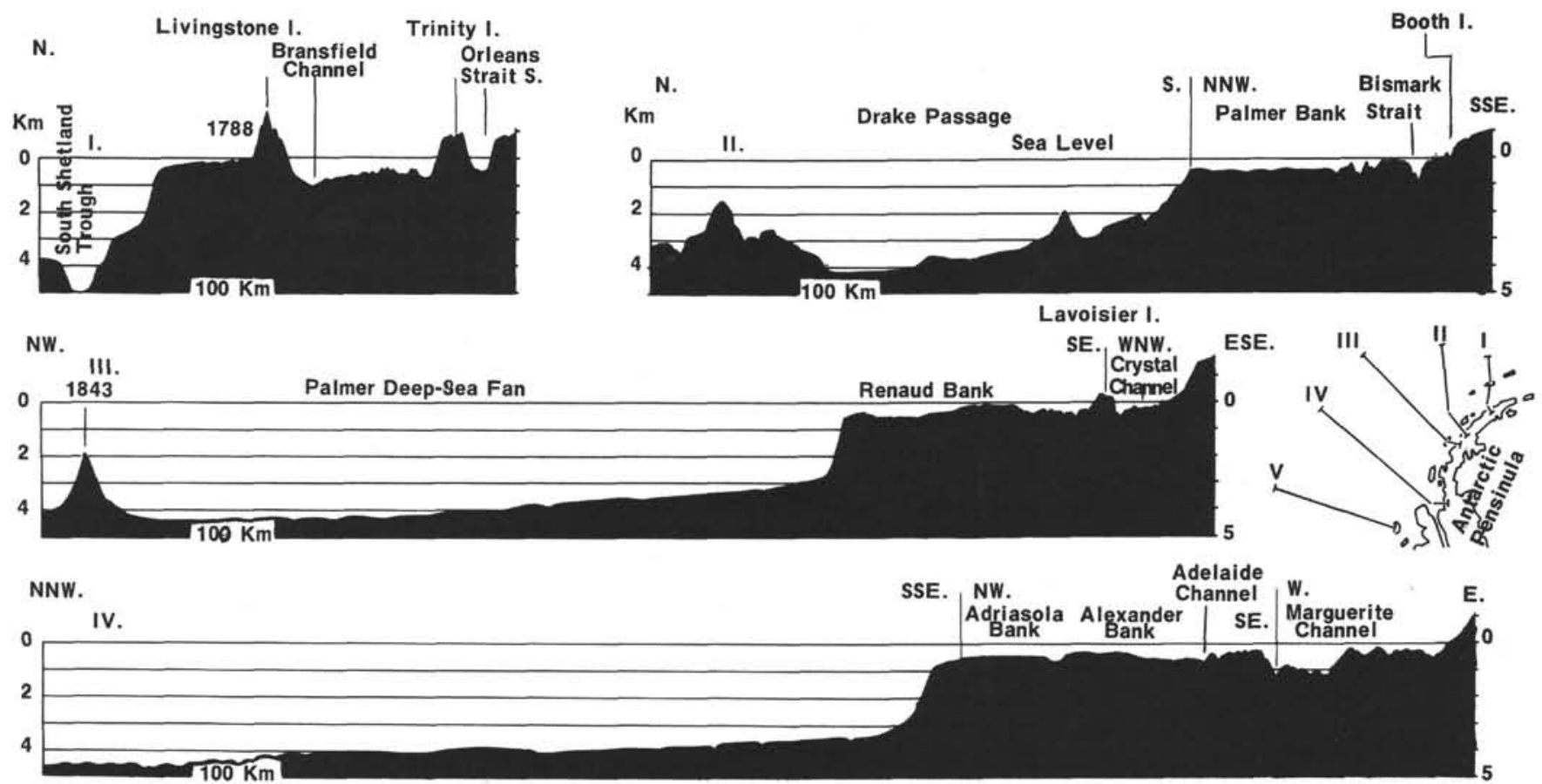

NW.

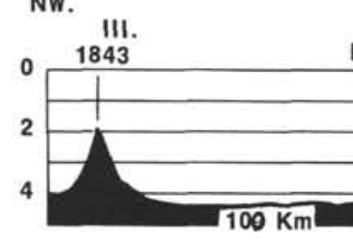

Palmer Deep-Sea Fan

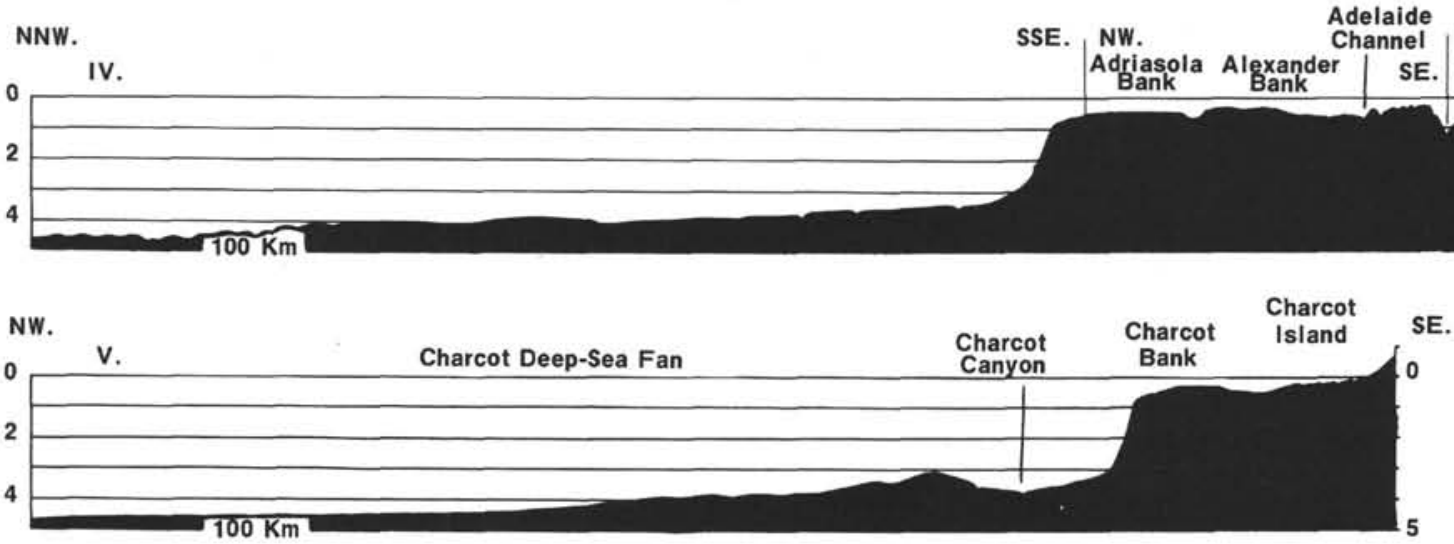

Figure 4. Bathymetric profiles. Note (1) steps in the slope and topographic contrasts in the deeper regions on the profiles I and II; (2) steep of the slope and width of the rise on the profiles $I I I, I V$, and $V$.

black) deeply hollowed between the insular shallow plateaus $(<10 \mathrm{~m})$. The declivity of the submarine slopes can exceed $500 \mathrm{~m} / \mathrm{km}$. To the south, Lavoisier and Marguerite channels $(>800 \mathrm{~m})$ form a similar trough.

The "transverse" channels are shorter than parallel channels and are a normal prolongation of the fjords. Their seaward extension forms the saddles between the banks of the outer shelf. Boyd, Hugo, Adelaide, Vostok, Wilkins, and Charcot channels (Figure 3) are examples. Their offshore terminations are formed by a counterslope similar to the terminal basin of the present fjords.

In both types of channels glacial morphology is prevalent, but the limits of the channels may reflect fault control. Seismic reflection data in Bransfield Strait reveal 300 meters of low velocity $(2-3.3 \mathrm{~km} / \mathrm{sec})$ sediments overlying more consolidated strata and thence a basement at a depth of 4-5 $\mathrm{km}$ with velocities of 4.2-4.3 km/sec (Cox, 1964; Griffiths and Barker, 1972). The low velocity unconsolidated sediments are assumed to be glacial debris. Surficial volcanic morphology is perhaps associated with the Bransfield Strait. Ashcroft (1974) suggested that the cones (Figure 5) reflect a line of volcanic events.

\section{Continental Slope and Rise}

The salient characteristics of the continental slope are its narrowness (20-60 km) and its steep slopes (average $12 \mathrm{~m} / \mathrm{km}$ ) (Figure 4). This high declivity seems to 


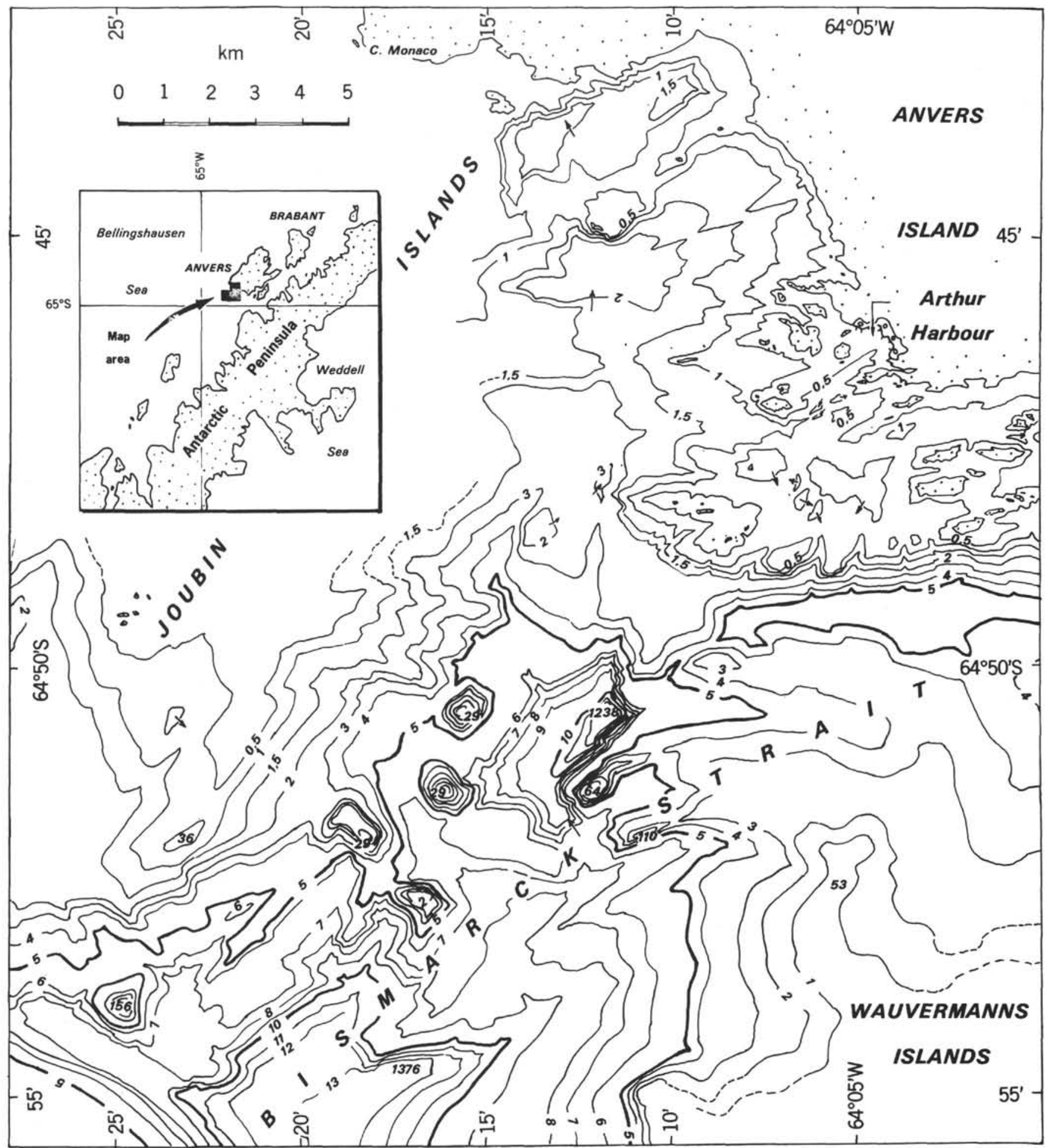

Figure 5. North Bismarck Strait and approaches of Arthur Harbor, bathymetric map. Contours in corrected hectometers. Numbers delineate shoal depths in meters. Note the conic forms in the channel.

decrease west of Charcot Island, but the soundings in this area of heavy pack ice (Figure 3 ) are too limited to establish this positively. Despite the paucity of confirming data, it appears that submarine canyons are probably as numerous as on other continental slopes. The canyon heads often indent deeply the shelf edge (i.e.,
Palmer, Adelaide, or Charcot canyons) and are apparent sometimes on the seaward side of saddles terminating the transverse channels.

The continental rise is an interesting geomorphic unit of the Antarctic margin. It generally lies between the 3000 and 4800 meter isobaths, is up to $500 \mathrm{~km}$ wide with 
a slope of $3.6 \mathrm{~m} / \mathrm{km}$, and bears a striking similarity to the eastern North America continental rise (Heezen et al., 1959). Three interesting geomorphic units lie within it and the adjacent ocean basin. (1) A seamount chain and a range of hills in the northern part, straddling $75^{\circ} \mathrm{W}$ between $60^{\circ}-65^{\circ} \mathrm{S}$; this belt of rugged topography is named Palmer Ridge by Tucholke and Houtz (this volume) and is a zone of high basement peaks behind which, in places, the continental rise sediments are ponded (Tucholke and Houtz, this volume). (2) Two deep-sea fans Palmer Cone (4000-4200 $\mathrm{m}$ isobaths) and, in the west, the Charcot Cone ( $4000-4600 \mathrm{~m}$ isobaths) have maximum breadths of about $400 \mathrm{~km}$. Deep-sea channels in the former apparently are not as deep as those of Charcot Cone, the latter reaching a depth of 200-400 meters below the adjacent sea floor. Channels are numerous in the central part of the continental rise; they are characterized by well-developed levees on the western sides, and traces of axial migration as revealed by underlying channels (Tucholke and Houtz, this volume, fig. 4, 21, 22). (3) Asymmetrical ridges at the base of the continental slope strike towards the west and southwest (i.e., west of Matha Bank, Figure 1). These forms, outlined by the isobaths between 3000 and 3600 meters (Figure 1) and for which we apply the name "abyssal drifts" (Vanney, 1973), appear to be like the Blake-Bahama Outer Ridges (Heezen et al., 1966; Johnson and Schneider, 1969; Markl et al., 1970).

At Site 325 , Leg 35 of the Deep Sea Drilling Project (Figures 3 and 6) 718 meters of Cenozoic sedimentary layers, consisting essentially of terrigenous detritus, clay, and claystone were cored (Hollister et al., 1974). These authors suggested igneous basement rock (or Layer 2) lies just beneath $(100 \mathrm{~m})$ the base of the cored interval and that the oldest deposits are probably Oligocene. However, E. Herron (personal communication, 1975) believes these dates to be too old, if Baker's interpretation on the magnetic anomalies in the Drake Passage is correct (Figure 7). To the south of Hero Fracture Zone the oceanic crust becomes younger eastward toward the foot of the slope and may be no older than 10 m.y. at Site 325 (Figure 7). The rise would thus be no older than late Miocene. If we suppose that $10 \mathrm{~m} . \mathrm{y}$. are necessary for the deposition of the continental rise, we note that the sedimentation rate calculated from early Pleistocene to present is $0.007 \mathrm{~cm} / \mathrm{yr}$. During the Miocene and early and middle Pliocene this rate was probably triple that of the Pleistocene $(0.02 \mathrm{~cm} / \mathrm{yr}$, Hollister et al., 1974), thus suggesting vigorous continental erosion during the progression of Antarctic inland ice. The volume of ice-rafted debris occurring in the upper 400 meters of Hole 325 documents the contribution of glacial erosion to the sediment supply of the continental rise (Figure 6). In all likelihood, the retreat of the ice caps and the submergence of the shelf resulted in a slowing down of the sedimentation rate. The time of deceleration is unknown.

\section{Ocean Basin}

The Bellingshausen Abyssal Plain occupies the northwestern part of the study area (Figures 1 and 3) with depths varying between 4700 and 5000 meters. The plain is flat with a general northward declivity of less than 0.4 $\mathrm{m} / \mathrm{km}$; a few abyssal hills are aligned along latitude $61^{\circ} \mathrm{S}$. Ewing et al. (1966) termed the plain the "Bellingshausen sediment body." It was drilled at Site 322 (Figure 2) to the underlying basalt. The tholeiitic basaltic basement was reached at the bottom of 513 meters of sedimentary deposits, which apparently have been accumulating since the Miocene (upper Miocene?) and consist from base upwards of 300 meters of turbidites, 120 meters of consolidated claystone, and 94 meters of sandstone and claystone. The sediment source most likely was Antarctica. The apparent lack of glacial marine deposits suggests that icebergs never reached this region. Hays (1967), Margolis and Kennett (1971), Weaver (1973), and Vanney and Dangeard (in press) suggested the region was covered by pack ice during maximum glaciation.

Drake Passage (Figure 3) includes three subdivisions: (1) In the west, stepped plateaus (probably volcanic), delineated by sinuous scarps the upper edge of which lies near the 3000 -meter isobath, are separated by narrow abyssal gaps scarcely wider than $10 \mathrm{~km}$; the authors suggest that future detailed surveys might reveal the fabric to be parallel to the magnetic lineations shown in Figure 7. (2) The topography of the basins which border the plateaus to the east is rough, with depressions delineated by the $3000-4000$ meter isobaths, and low ridges oriented northeast-southwest; within them are low seamounts (i.e., the chain along $65^{\circ} \mathrm{W}$ ). (3) On the southeast part of Drake Passage and at the base of the Antarctic slope lies the South Shetlands Trough. It is a deep asymmetrical trench made up of at least two flat-bottom basins communicating through a narrow gap. The southwest trench reaches 4600 meters depth whereas the northeastern one does not exceed 5000 meters depth. The trough is the postulated course used by the eastward migration of sediments (Ewing et al., 1966).

The topographic features in (1) and (2) above are probably controlled by fracture zones, lying to the southeast of the Shackleton Fracture Zone, which clearly offset the magnetic lineations discovered by Barker (1972a) (Figure 3). Herron and Tucholke (this volume) have delineated two which they have named Hero and Tula. Barker postulated that the South Shetland trenches are a subduction zone in which the oceanic crust (Aluk plate, Herron and Tucholke, this volume) is subducted under the northern termination of the Antarctic Peninsula.

\section{GENERAL REMARKS}

The continental margin of the western part of the Antarctic Peninsula has been influenced by two main evolutionary factors, sea-floor spreading and climate. Two independent sea-floor spreading centers appear to have operated in the region. One, in the Scotia Sea, created a major part of the crust within the last 40 m.y. (Ewing et al., 1971; Barker, 1972b; Barker and Griffiths, 1972; Davey, 1972; Griffiths and Barker, 1972).

The other, in the South Pacific and active since Late Cretaceous, has shifted the New Zealand-Chatham Rise block to its present location (Herron, 1971; Molnar et al., 1975). However, the configuration and the numeration of the magnetic anomalies detected beaneath the continental rise of the Antarctic Peninsula seem to 


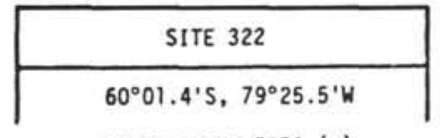

NATER DEPTH $5026(\mathrm{~m})$

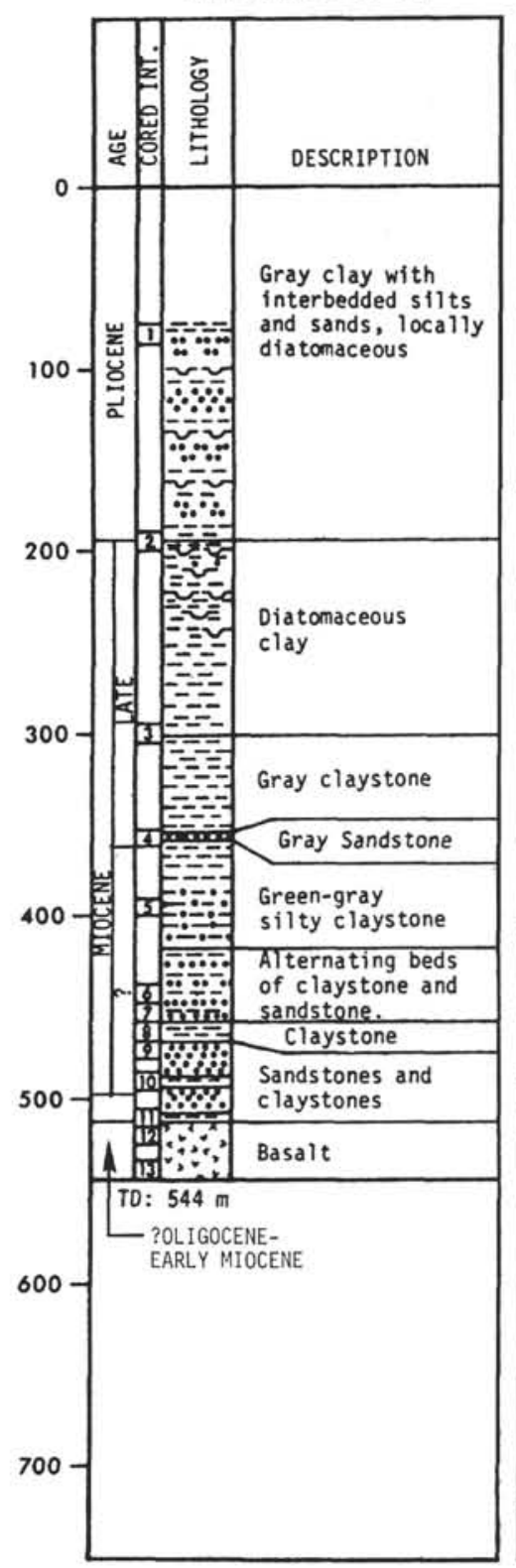

\begin{tabular}{|c|}
\hline SITE 325 \\
\hline $65^{\circ} 02.8^{\prime} \mathrm{S}, 73^{\circ} 40.4^{\prime} \mathrm{W}$ \\
WATER DEPTH $3745(\mathrm{~m})$
\end{tabular}

WATER DEPTH 3745 (m)

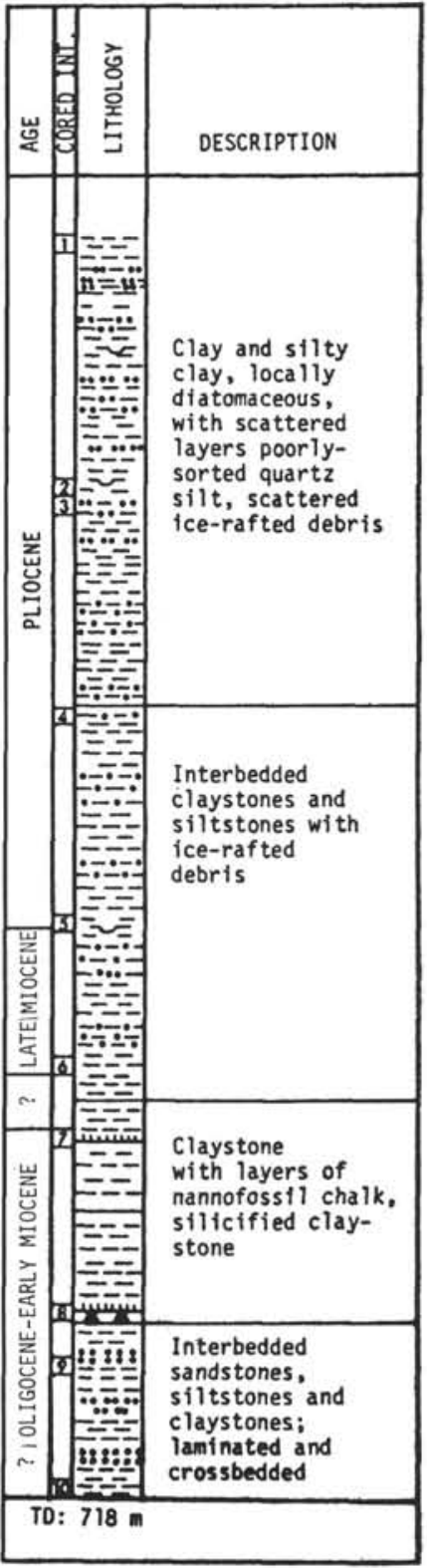

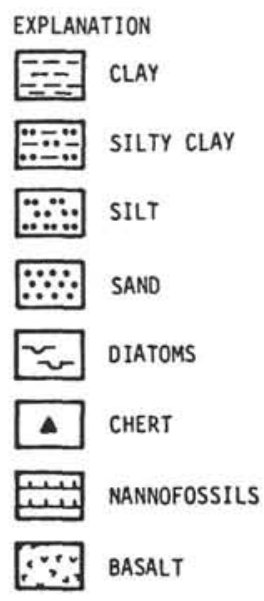

Figure 6. Log of two holes of Leg 35, based on Hollister et al. (1974).

indicate that an autonomous sea-floor spreading center has been operating in the Bellingshausen basin (Pitman et al., 1974). The magnetic anomaly pattern might be explained (Figure 7) by a triple junction which has been subducted beneath the Antarctic Peninsula (McKenzie and Morgan, 1969). Because triple junctions are assumed to be coincident with "hot spots" or "mantle plumes," the presence of one in this region might relate to the formation of the tabular topographic seamounts, the construction of a minor seamount chain, and generally, the extensive shoaling of the western Drake Passage. According to this explanation a ridge crest would be beneath the continental margin west of $70^{\circ}$.
The relation between this hypothetical "hot spot" and the volcanic activity on Deception Island is unknown. Substantial evidence of subduction on the Antarctic Peninsula exists (Dalziel et al., 1974) although ophiolitic rocks are unknown in western Antarctica. Since the time of subduction, the Antarctic margin has been inactive except in the north where subduction under the South Shetland Trough is evidenced by volcanism and earthquake epicenters.

The controlling tectonic pattern, therefore, is probably the result of uplift associated with a "hot spot" and its related triple junction and associated fracture zones. The subduction of the oceanic crust along the Antarctic 


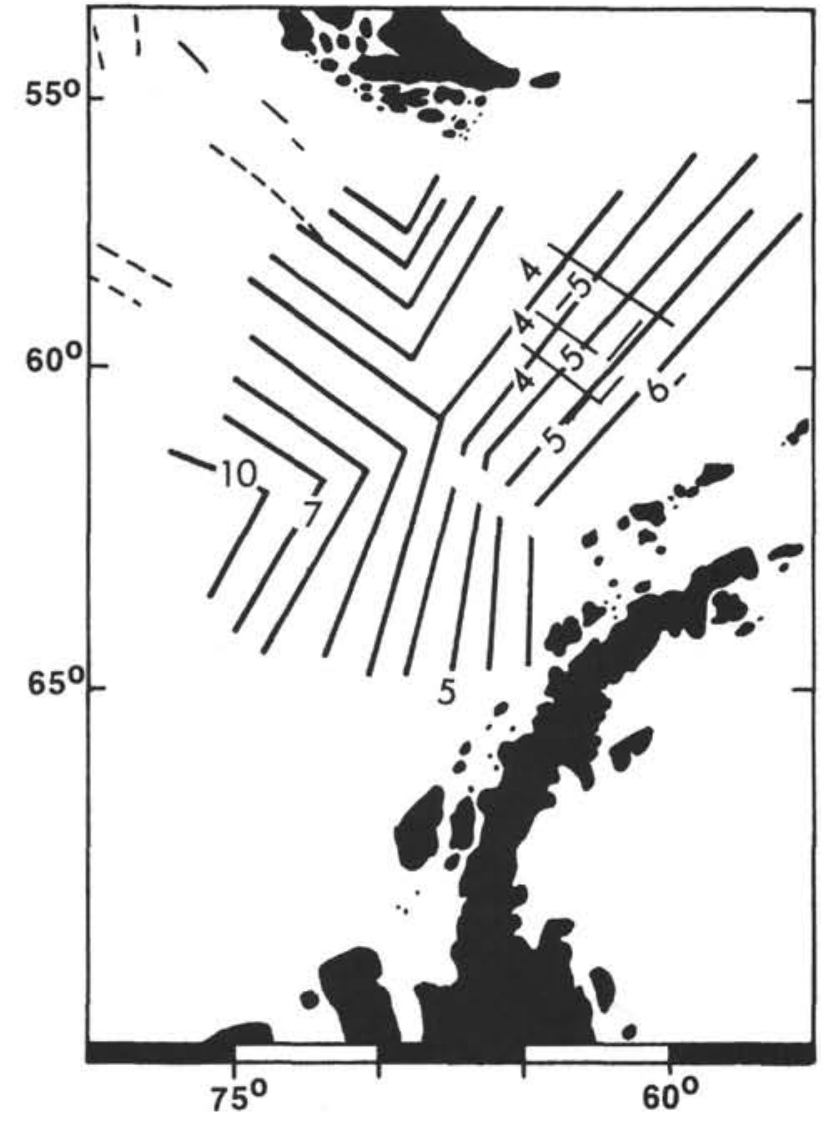

Figure 7. Possible orientation of the magnetic anomalies to the NW of the Antarctic Peninsula. Numbers refer to magnetic anomalies and one schematic.

continental margin has uplifted the Antarctica Mountains with associated rift structures and volcanic events (Dalziel et al., 1974). The larger depressions (i.e., Bransfield Strait) are apparently the result of extensional processes as is suggested by the presence of intermediate crust (Griffiths and Barker, 1972) as well as its steep fault controlled walls. These extensional phenomena are similar to those suggested by Karig $(1970,1972)$ in the insular arcs of the West Pacific.

The second major influence on the morphology of the Antarctic continental margin is the climate. During the growth stages and maximal extension of the glaciers, erosion was extended to the outer reaches of the continental shelf. Normal prolongation of inland valley glaciers, and the flow of effluents produced an overdeepening and enlarging of the transverse valleys with the marginal fractures being incised by the glaciers. The outer shelf "banks" were probably constructed by terminal moraines of the glaciers. It is undoubtedly the rafting of these materials that resulted in the deposition of coarse glacial material above the continental slope.

The unusual depth of the outer shelf is perhaps due to the overloading by inland ice (1 to $2 \mathrm{~km}$, Voronov, 1960) and incomplete postglacial isostatic rebound because of the persistence of thick ice caps on the mainland. According to the concept developed in the Soviet literature for the portions of the eastern Antarctic continental margin, the longitudinal shelf depressions are perhaps related to fracturing dependent upon the extent and thickness of the ice load. The longitudinal channels would be a glacio-dislocation line between the continental inner shelf alternatively uplifted and depressed, and the offshore sea floor. As Guilcher (1963) put forward, it is possible to combine the tectonic and glacial explanations insofar as Cenozoic faulting has predisposed the isostatic "breathing" along faults. Holtedahl (1970) and Johnson et al. (1975), studying the continental margins in the northern hemisphere, believe the longitudinal channels represent the boundary between the crystalline high velocity Paleozoic and Pre-Cambrian rocks and low velocity Mesozoic rocks deposited in epicontinental basins at the initiation of continental drift. This hypothesis may be valid for Antarctica also, with the sea bed seaward of the longitudinal channels consisting of Mesozoic sequences formed when Gondwanaland was undergoing initial rifting. The longitudinal channels would represent Mesozoic antithetic fault traces subsequently scoured by glacial action.

The present authors thus believe that the morphological development of the Antarctic continental margin is the result of structural processes, such as subduction, rifting, and sea floor spreading, modified by vigorous glacial processes which occurred during the lower sea levels of Plio-Pleistocene time.

\section{ACKNOWLEDGMENTS}

We are grateful to the Defense Mapping Agency and Lamont-Doherty Geological Observatory for supplying sounding data and to E. Herron of Lamont-Doherty for preprints of her unpublished magnetic data. Thanks are due to Commodore D.C. Kapoor, Director of the IHB (International Hydrographic Bureau) of Monaco, and to the Hydrographer of the Navy, Great Britain for sounding data. A. Guilcher, U.B.O. Brest, H. Holtedahl, University of Bergen, and C. Hollister, Woods Hole Oceanographic Institute, read the text and offered many helpful suggestions.

\section{REFERENCES}

Adie, R.J., 1964. Sea level changes in the Scotia Arc and Graham Land. In Adie, R.J. (Ed.), Antarctic geology: Amsterdam (North-Holland Publ. Co.), p. 27-32.

1972. Recent advances in the geology of the Antarctic Peninsula. In Adie, R.J. (Ed.), Antarctic geology and geophysics: Oslo (Universitets-forlaget), p. 121-124.

Araya, R. and Herve, F., 1972. Periglacial phenomena in the South Shetland Islands, In Adie, R.J. (Ed.), Antarctic geology and geophysics: Oslo (Universitets-forlaget), p. 105-109.

Ashcroft, W.A., 1974. Crustal structure of the South Shetland Islands and Bransfield Strait: Sci. Rept. British Ant. Surv., v. 66, p. $1-43$.

Barker, P.F., 1972a. Magnetic lineations in the Scotia Sea. In Adie, R.J. (Ed.), Antarctic geology and geophysics: Oslo (Universitets-forlaget), p. 17-26.

1972b. Plate tectonics of the Scotia Sea region: Nature, v. 228 , p. 1293.

Barker, P.F. and Griffiths, D.H., 1972. The evolution of the Scotia Ridge and Scotia Sea: Phil. Trans. Roy. Soc. London, Ser. A, v. 271, p. 151-183.

Calkin, P.E. and Nichols, R.L., 1972. Quaternary studies in Antarctica. In Adie, R.J. (Ed.), Antarctic geology and geophysics: Oslo (Universitets-forlaget), p. 625-643. 
Carey, S.W. and Ahmad, N.S., 1961. Glacial marine sediments. In Raasch, G.O. (Ed.), Geology of the Arctic: Toronto (Toronto Univ. Press), v. 2, p. 865-894.

Charcot, J.B., 1906. Le 'Français' au Pôle Sud. Suivi d'un exposé de quelques-uns des travaux scientifiques par les membres de l'Etat-Major M.M. Matha, Rey, Pleneau, Turquet, Gourdon, Charcot: Paris (E. Flammarion). 1910, Paris

1910. Le 'Pourquoi-Pas?' dans l'Antarctique, 1908-

Cox, M.J.G., 1964. Seismic refraction measurements in Bransfield Strait: British Ant. Surv. Bull., v. 4, p. 1-12.

Dalziel, W.D., Wit, M.J. de, and Palmer, K.F., 1974. Fossil marginal basin in the Southern Andes: Nature, v. 250, p. 291-294.

Dangeard, L. and Vanney, J.R., in press. Essai de classification des depots glacio-marins, d'apres l'examen des photographies sousmarines: Ann. Inst. Oceanogr.

Dangeard, L., Vanney, J.R., and Johnson, G.L., in preparation. Etude photographique des fonds du Bassin de Bellingshausen (Pacifique du Sud-Est).

Davey, F.J., 1972. Marine gravity measurements in Bransfield Strait and adjacent areas. In Adie, R.J. (Ed.), Antarctic geology and geophysics: Oslo (Universitets-forlaget), p. 39 45.

Ewing, M., Ewing, J.I., Houtz, R.E., and Leyden, R., 1966. Sediment distribution in the Bellingshausen Basin. In Symp. Antarctic Oceanogr.

Ewing, J.I., Ludwig, W.J., Ewing, M., and Eittrem, J.L., 1971. Structure of the Scotia Sea and Falkland Plateau: J. Geophys. Res., v. 76, p. 7118-7137.

Flores Silva, E., 1952. Observaciones de costas enla Antartida chilena: Inform. Geograficas, v. 2, p. 667-675.

1972. Geomorphological observations and Generalizations on the Coasts of the South Shetland Islands and Antarctic Peninsula. In Adie, R.J. (Ed.), Antarctica geology and geophysics: Oslo (Universitetsforlaget), p. 99-103.

Fuenzalida, H., 1964. Coastal phenomena in the South Shetland Islands. In Adie, R.J. (Ed.), Antarctica geology and geophysics: Oslo (Universitets-forlaget), p. 48-52.

Gerlache, A. de, 1902. Quinze mois dans l'Antarctique: Paris (Hachette).

Gourdon, E., 1908. Geographie physique, Glaciologie, Petrographie des regions visitees par l'expedition antarctique française commandee par le Dr. Charcot (1903-1905): Paris (Masson).

1914. Sur la constitution mineralogique des Shetlands du Sud: C.R. Acad. Sci., Paris, v. 158, p. 19051907.

Griffiths, D.H. and Barker, P.F., 1972. Review of marine geophysical investigations in the Scotia Sea. In Adie, R.J. (Ed.), Antarctica geology and geophysics: Oslo (Universitets-forlaget), p. 3-11.

Guilcher, A., 1963. Continental shelf and slope (Continental Margin). In Hill, M.N. (G. Ed.), The sea, ideas and observations on progress in the study of the seas: New York and London, (Interscience Publishers), v. 3, p. 281-311.

Hays, J.D., 1967. Quaternary sediments in the Antarctic Ocean. In Sears, M. (Ed.), Progress in oceanography: New York (Pergamon Press), v. 4, p. 117-131.

Heezen, B.C., Hollister, C.D., and Ruddiman, W.F., 1966. Shaping of the continental rise by deep geostrophic contour current: Science, v. 152 , p. 502-508.

Heezen, B.C., Tharp, M., and Ewing, M., 1959. The floors of the oceans. The North Atlantic: Geol. Soc. Am. Spec. Paper 65, p. 1-122.

Herron, E.M., 1971. Crustal plates and sea floor spreading in the Southeastern Pacific. In Reid, J.L. (Ed.), Biology of the Antarctic Seas, IV: Antarctic Res. Series, v. 15, p. 229-237.
Hollister, C.D., Craddock, C., Bogdanov, J.A., Edgar, N.T., Gieskes, J., Haq, B.U., Lawrence, J., Rögl, F., Schrader, H.-J., Tucholke, B.E., Vennum, W., and Weaver, F.M., 1974. Deep Drilling in the Southeast Pacific Basin: Geotimes, v. 8, p. 1619.

Holtedahl, O., 1929. On the geology and physiography of some Antarctic and subantarctic Islands: Sci. Res. Norway Antarctic Exped., v. 3, p. 1-172. 1970. Morphology of the west Greenland shelf with general remarks on the "marginal channel" problem: Marine Geol., v. 8, p. 155-172.

Institut de France, Académie des Sciences, 1910. Rapports préliminaires sur les travaux exécutés dans l'Antarctique par la mission commandée par M. le Dr. Charcot: Paris (Gauthier-Villars).

Johnson, G.L. and Schneider, E.D., 1969. Depositional in the North Atlantic: Earth Planet. Sci. Lett., v. 6, p. 416-422.

Johnson, G.L., McMillan, N.J., and Egloff, J., 1975. East Greenland Continental Margin. In Yorath, C., Parker, E.R., and Glass, D.J. (Eds.), Canadian Continental Margins and offshore petroleum exploration: Can. Soc. Petrol. Geol., Mem. 4, p. 205-224.

Joyce, J.R.F., 1950. Notes on ice-foot development, Neny Fjord, Graham Land, Antarctica: J. Geol., v. 58, p. 646649.

Karig, D.E., 1970. Ridges and basins in the Tonga-Kermadec island arc system: J. Geophys. Res., v. 67, p. 239-254.

p. $1057-1067$

King, L.H., 1969. Submarine end moraines and associated deposits on the Scotian shelf: Geol. Soc. Am. Bull., v. 80, p. 83-96.

1970. Surficial geology of the Halifax-Sable Island map area. Dept. Energy, Mines, and Resources, Ottawa, Mar. Sci. Branch, Paper no. 1, p. 1016.

McKenzie, D.P. and Morgan, W.J., 1969. Evolution of triple junctions: Nature, v. 244, p. 125-133.

Margolis, S.V. and Kennett, J.P., 1971. Cenozoic paleoglacial history of Antarctica recorded in subantarctid deep-sea cores: Am. J. Sci., v. 271, p. 1-36.

Markl, R.G., Bryan, G.M., and Ewing, J.I., 1970. Structure of the Blake-Bahama Outer Ridge: J. Geophys. Res., v. 75, p. $4539-4555$.

McLean, B. and King, L.H., 1971. Surficial geology of the Banquereau and Misaine Bank map area: Geol. Surv. Canada, Paper 71-52, p. 1-9.

Molnar, P., Atwater, T., Mammerickx, J., Smith, S.M., 1975. Magnetic anomalies, bathymetry, and the tectonic evolution of the South Pacific since the late Cretaceous: Geophys. J. Roy. Astron. Soc., v. 40, p. 383-420.

Nichols, R.L., 1960. Geomorphology of Marguerite Bay area, Palmer Peninsula, Antarctica: Geol. Soc. Am. Bull., v. 71. 1964. Geomorphology of Antarctica. In Antarctic Res. Ser. 8.

Pitman, W.C., III, Larsen, R.L., and Herron, E.R., 1974. Magnetic lineations of the oceans: Geol. Soc. Am. Boulder, Colorado.

Rouch, J., 1928. La temperature et les courants de la mer dans l'Antarctide: Am. Inst. Oceanogr. Bull., Monaco, no. 520. 1957. L'Antarctide Américaine (Etude Météorologique): Am. Inst. Oceanogr. Bull., Monaco, no. 1095.

Sommerhoff, G., 1973. Formenschatz und morphologische Gliederung des subestgronlandischen Schelfgebiets unf Kontinentalabhanges: Meteor Forsch.-Ergebnisse, v. 15, p. 1-54.

Vanney, J.R., 1973. Geomorphologie sous-marine. In Geloussov, V.V., Muraour, P., and Vanney, J.R., Structure et geomorphologie dynamiques des fonds marins: Paris (Masson), v. 1, p. 1-78. 
Vanney, J.R. and Dangeard, L., in press. Les depots glaciomarins actuels et anciens: Rev. Geogr., Montreal.

Voronov, P.S., 1960. Tentative reconstitution of the Antarctic Islands during the glacial maximum (in Russian): Inf. Biul. Sov. Ant. Exp., v. 23, p. 15-19.

Warnke, D.A. and Richter, J., 1970. Sedimentary petrography of till from a floating iceberg in Arthur Harbor, Antarctica
Peninsula: Arev. Geogr. Phys. Geol. Dyn., v. 12, p. 441448.

Weaver, F.M., 1973. Pliocene paleoclimate and paleoglacial history of East Antarctica recorded in deep-sea piston cores: Sedimentology Res. Lab., Dept. Geol., Florida State Univ., Tallahassee, Fla., Contrib. No. 36.

Zhivago, A.V. and Evteev, S.A., 1970. Shelf and marine terraces of Antarctica: Quaternaria, v. 12, p. 89-114. 